\title{
Reversal of paraparesis after thoracic aneurysm repair by cerebrospinal fluid drainage
}

\author{
Binh Khong BSc MD, * \\ Homer Yang MD, * \\ B. Doobay MBBs, $\uparrow$ \\ Richard Skala MSc MD*
}

Purpose: To describe a case of reversal of delayed paraparesis, after an elective type I thoracoabdominal aortic aneurysm (TAAA) repair, via cerebrospinal fluid (CSF) drainage.

Clinical Features: A 75-yr-old woman developed paraparesis $13 \mathrm{hr}$ after type I TAAA repair. The patient had been given combined regional and general anesthesia. There was no cerebrospinal fluid drain inserted at the time of surgery. The patient was hemodynamically stable throughout the procedure and was transported to the intensive care unit with trachea intubated and lungs ventilated. She demonstrated some initial lower limb paraparesis but had good recovery of limb function three hours after cessation of the epidural infusion. However, five hours and forty-five minutes after stopping the epidural, she was again paraparetic. Peripheral nerve injury, prolonged effects of epidural local anesthetic, and epidural hematoma were ruled out as precipitating factors. Cord ischemia was considered possible and a CSF catheter was inserted. Immediate improvement was seen upon catheter insertion and commencement of drainage, beginning with movement in the left toes and foot. Drainage was performed when the CFS pressure became $>15 \mathrm{mmHg}$. Motor function in the lower limbs continued to improve with each drainage extending to complete recovery after $40 \mathrm{hr}$. She was discharged home I I days after surgery with no neurological deficit.

Conclusion: Drainage of CSF was useful in treating a case of post-TAAA neurologic deficit.

Objectif: Décrire le cas d'un renversement de paraparésie différée, à la suite d'un drainage du liquide céphalorachidien (LCR), survenue après la réparation d'un anévrisme aortique thoraco-abdominal (AATA) de type I.

Éléments cliniques : Une femme de 75 ans a été victime d'une paraparésie, 13 h après la réparation d'un AATA de type I. Elle a reçu une anesthésie régionale et générale combinée. A ce moment, on n'avait pas inséré de drain pour le liquide céphalo-rachidien. La patiente a présenté une hémodynamie stable tout au long de l'opération et a été transportée à l'unité des soins intensifs intubée et ventilée. Une paraparésie des membres inférieurs s'est d'abord manifestée, mais une bonne récupération de la fonction est survenue trois heures après le retrait de la perfusion péridurale. Toutefois, cinq heures et quarante-cinq minutes après la fin de la perfusion, la paraparésie est réapparue. Une lésion du nerf périphérique, des effets prolongés de l'anesthésique local péridural et un hématome péridural ont été exclu comme facteurs précipitants possibles. Une ischémie médullaire étant soupçonnée, nous avons inséré un cathéter dans le LCR. Une amélioration immédiate a été observée, dès le début du drainage, par des mouvements des orteils et du pied gauches. Le drainage a été réalisé lorsque la pression du LCR est devenue > $15 \mathrm{mmHg}$. La fonction motrice des membres inférieurs s'est améliorée avec chaque drainage jusqu'à une récupération complète après 40 h. La patiente a reçu son congé I I jrs après l'intervention et ne présentait pas de déficit neurologique.

Conclusion : Le drainage du LCR a été utile dans le cas d'un déficit neurologique survenu à la suite de la correction d'un AATA.

From the Departments of Anesthesia* and Surgery, $†$ McMaster University and Hamilton Health Sciences Corporation, Hamilton, Ontario, Canada.

Address correspondence to: Dr. Homer Yang, Department of Anesthesia, Room 2Ul, McMaster University, 1200 Main St W., Hamilton,

Ontario, L8N 3Z5 Canada. Phone: 905-521-2100; Fax: 905-523-1224; E-mail: yangh@fhs.mcmaster.ca

Accepted for publication July 2, 2000. 
$\mathrm{T}$

HE incidence of paraplegia in patients after repair of thoracoabdominal aortic aneurysm (TAAA) ranges from $6.5 \%$ to $40 \% .^{1}$ Patients at greatest risk are those with Crawford types I, II, or emergent dissection. ${ }^{2,3}$ Factors postulated to decrease the incidence of paraplegia include decreased aortic cross-clamp time, reimplantation of intercostal arteries, hypothermia, or CSF drainage. ${ }^{1}$

The proposed mechanism of the benefit of CSF drainage in paraparesis is reduction of CSF pressure and the improvement in spinal cord perfusion pressure. Nevertheless, a recent review article concluded that the evidence for this practice is weak since all clinical trials to date have methodological flaws. ${ }^{4}$ Two cases were reported in 1994 where paraplegia was reversed with CSF drainage after thoracic aortic surgery. ${ }^{5}$ In 1997, eight cases of delayed neurological deficit were seen after thoracoabdominal aortic aneurysm repair. The CSF drainage was instituted upon discovery of paraplegia. At the time of discharge, two patients had complete recovery of their neurological deficits, two had residual paraparesis, and four had considerable but incomplete motor recovery with motion against gravity. 6 We report a patient who developed paraparesis after thoracic aneurysm repair, and its reversal with CSF drainage.

\section{Case report}

A 74-yr-old woman, with a 15 pack-year smoking history and previous breast cancer, presented for elective repair of a thoracic aneurysm. There was no other history of previous medical problems, including previous neurological deficits. The patient was sedated with 3 $\mathrm{mg}$ midazolam and an epidural catheter was inserted at $\mathrm{T}_{8-9}$. The insertion was uneventful and was well tolerated by the patient. Epimorph, $5 \mathrm{mg}$, was given at $0810 \mathrm{hr}$ and $5 \mathrm{ml}$ bupivacaine, $0.125 \%$, were given at $1100 \mathrm{hr}$. At $0820 \mathrm{hr}$, anesthesia was induced with 50 $\mu \mathrm{g}$ sufentanil, $60 \mathrm{mg}$ propofol and tracheal intubation was facilitated with $50 \mathrm{mg}$ rocuronium. Anesthesia was maintained with halothane and neuromuscular blockade with pancuronium. She was placed in the right lateral decubitus position for a left posterolateral thoracotomy. Before cross-clamping, the patient received 2000 IU heparin. The aorta was crossclamped for $35 \mathrm{~min}$ at the level of the isthmus of the aorta just below the left subclavian artery. No shunt was placed before application of the cross-clamp and hypothermia was not instituted. The intercostal arteries at the upper anastomosis, a bunch of three, were implanted. Total anesthetic time was four hours. Intraoperative blood loss was estimated to be 1000 $\mathrm{ml}$; intraoperative fluid replacement included two units of packed red cells, $500 \mathrm{ml}$ Pentaspan, and 6000 $\mathrm{ml}$ crystalloid. No episodes of intraoperative hypotension were noted. Postoperatively, the patient was admitted to the ICU at $1210 \mathrm{hr}$, the trachea was intubated and the lungs were ventilated. The postoperative hemoglobin concentration was $109 \mathrm{~g} \cdot \mathrm{L}^{-1}$. By $1340 \mathrm{hr}$, an infusion of bupivacaine $0.125 \%$ and 4 $\mu \mathrm{g} \cdot \mathrm{ml}^{-1}$ fentanyl at $10 \mathrm{ml} \cdot \mathrm{hr}^{-1}$ through the epidural catheter was established. By $1500 \mathrm{hr}$, although intubated, she was alert and obeying commands. Her pupils were equal and reactive, and mild weakness in both arms and legs were noted, attributed to the residual effects of non-depolarizing muscle relaxants.

At $1900 \mathrm{hr}$, vital signs were stable but she was unable to move either leg, and the epidural infusion rate was decreased to $5 \mathrm{ml} \cdot \mathrm{hr}^{-1}$. Slight decrease to pinprick was noted at the time. At $2000 \mathrm{hr}$, the vascular surgeon was notified and the epidural infusion discontinued. At $2015 \mathrm{hr}$, she was able to move her right toes, and by $2145 \mathrm{hr}$, she was able to move the right foot well. At $2300 \mathrm{hr}$, she was able to move her left leg, flex both feet and knees but was not yet able to lift her legs against gravity. Hemodynamic variables were normal throughout the episode.

At $0100 \mathrm{hr}$, the trachea was extubated. By $0145 \mathrm{hr}$, she was again unable to move either lower limb. No paresthesia was noted at that time. A CT myelogram was performed at $0250 \mathrm{hr}$ which showed osteophytes in the spinal canal, a small collection of air in the epidural space, but no evidence of epidural hematoma or spinal cord compression. By $0430 \mathrm{hr}$, she was able to move her right leg but her left leg remained paretic. At $0530 \mathrm{hr}$, her epidural catheter was removed. She was sedated with $2 \mathrm{mg}$ midazolam $i v$ and placed in the right lateral position. A silastic CSF drain was inserted at $\mathrm{L}_{3-4}$ via a $14 \mathrm{ga}$. Tuohy needle. It was estimated that $15-20 \mathrm{ml}$ CSF were lost during the attempt to thread the catheter. Within one minute of the lumbar drain placement, she was able to move her left toes and foot. By $0645 \mathrm{hr}$, she continued to move her right leg well but now was able to flex her left knee slightly. Drainage of CSF was ordered whenever CSF pressure was $>15 \mathrm{mmHg}\left(20 \mathrm{~cm} \mathrm{H}_{2} \mathrm{O}\right)$.

At $0800 \mathrm{hr}$ of the following day (first post-op day), the left leg remained weak while the right leg demonstrated normal power. Due to a change in personnel, CSF drainage was not undertaken during the remainder of the day. At $2000 \mathrm{hr}$, CSF pressure was noted to be $>15 \mathrm{mmHg}$ and $10 \mathrm{ml}$ CSF were drained. Complete resolution of paraparesis was noted after the drainage. Repeated CSF drainage when the pressure was $>15 \mathrm{mmHg}$ was undertaken. A total of $140 \mathrm{ml}$ CSF was drained over $40 \mathrm{hr}$. On the third day post-op, 
the lumbar drain was removed and the patient was transferred to the vascular step-down unit. On the seventh day post-op, she was transferred to a regular ward and discharged home on the eleventh day with no neurological sequelae.

\section{Discussion}

The initial differential diagnosis for this patient's paraparesis included nerve injury from either surgical dissection or retraction, prolonged effects of local anesthetic, anterior spinal artery thrombosis, epidural hematoma, and spinal cord trauma during epidural catheter insertion. The insertion of the epidural catheter was undertaken when the patient was awake and was uneventful; spinal cord trauma was considered unlikely. The distribution of the neurological deficits was atypical of nerve or nerve trunk injury. The presence of slight paresthesia with paraparesis would make the prolonged effects of epidural bupivacaine a possible culprit initially and improvement of the paraparesis after discontinuing the epidural infusion seemed to confirm the hypothesis.

However, approximately five hours after the epidural infusion was discontinued, lower limb paraparesis returned and it was felt necessary to rule out an epidural hematoma. The negative CT myelogram was reassuring but necessitated formulation of other differential diagnoses. The possibility of anterior spinal artery pathology with spinal cord ischemia was then considered. The relapsing nature of the neurological signs suggested compromise of anterior spinal arterial blood flow but not thrombosis. Since the blood pressure remained normal throughout the paraparesis, a possible explanation would be anterior spinal artery spasm or reperfusion injury.

After the release of an aortic cross-clamp, increased blood flow and delivery of oxygen to the ischemic areas of the spinal cord may cause a surge of free radical production. ${ }^{7}$ These free radicals may damage glial cells, cause cord edema, or decrease post-reperfusion blood flow in the previously ischemic segment. ${ }^{8}$ This decrease in blood flow may be secondary to vasoconstriction from endothelin and thromboxane, metabolites from reactions of the free radicals and membrane lipids. ${ }^{9}$ The neurological injury would then be a type of reperfusion injury. Although endothelin may bind on to receptor sites and exert its effects for many hours, ${ }^{10}$ it is unknown if the resulting neurological deficits would present in a relapsing fashion.

Spinal cord perfusion pressure (SCPP) is the difference between mean arterial pressure (MAP) and cerebrospinal fluid pressure (CSFP). Theoretically, increasing MAP or decreasing CSFP would improve
SCPP. The patient presented here experienced delayed paraplegia and intermittent paraparesis post-op but normal blood pressure. Once other causes had been ruled out, cord ischemia was considered possible, and she was treated as such: CSF pressure was maintained $<15 \mathrm{mmHg}$ although the optimal CSF pressure level has not been determined. Safi et al. ${ }^{2}$ kept the CSF pressure of their experimental groups less than 10 and $15 \mathrm{mmHg}$. There was no difference in outcomes between the two groups in terms of neurological deficits. Hill et al. ${ }^{5}$ reported keeping CSF pressure less than $10 \mathrm{mmHg}$ for their two cases of reversal of paraplegia post TAAA once CSF drainage was instituted. The maintenance level used in this case is consistent with these reported levels.

Interestingly, in this patient, there was a temporal relationship between CSF drainage and neurological improvement. Motor function in her lower limbs improved immediately after CSF was drained and continued to improve with each subsequent drainage. Even though the evidence in the literature for CSF drainage is scant, the course of events in this patient suggests that CSF drainage may be useful in treating post-TAAA neurological deficits.

Acknowledgments

The authors thank Dr. Kris Wilson-Yang for her assistance in preparing this report for publication.

\section{References}

1 McCullough JL, Hollier LH, Nugent M. Paraplegia after thoracic aortic occlusion: influence of cerebrospinal fluid drainage. J Vasc Surg 1988; 7: 153-60.

2 Safi HJ, Hess KR, Randel M, et al. Cerebrospinal fluid drainage and distal aortic perfusion: reducing neurologic complications in repair of thoracoabdominal aortic aneurysm types I and II. J Vasc Surg 1996; 23: 223-8.

3 Acher CW, Wynn MM, Hoch JR, Kranner PW. Cardiac function is a risk factor for paralysis in thoracoabdominal aortic replacement. J Vasc Surg 1998; 27: 821-30.

4 Ling E, Arellano R A systematic overview on the evidence for cerebrospinal fluid drainage in thoracoabdominal surgery for prevention of paraplegia.

Anesthesiology 2000; (in press).

5 Hill AB, Kalman PG, Johnston KW, Vosu HA. Reversal of delayed-onset paraplegia after thoracic aortic surgery with cerebrospinal fluid drainage. J Vasc Surg 1994; 20: 315-7.

6 Safi H, Miller CC III, Azizzadeh A, Iliopoulos DC. Observations on delayed neurologic deficit after thoracoabdominal aortic aneurysm repair. J Vasc Surg 1997; 26: 616-2. 
7 Kukreja RC, Hess ML. The oxygen free radical system: from equations through membrane-protein interactions to cardiovascular injury and protection. Cardiovasc Res 1992; 26: 641-5.

8 Del Maestro RF, Thaw HH, Björk J, Planker M, Arfors $K-E$. Free radicals as mediators of tissue injury. Acta Physiol Scan 1980; 492: 43-57.

9 Reid JL, Dawson D, Macrae IM. Endothelin, cerebral ischaemia and infarction. Clin Exp Hypertens 1995; 17: 399-407.

10 Clarke JG, Benjamin N, Larkin SW, Webb DJ, Davies GJ, Maseri A. Endothelin is a potent long-lasting vasoconstrictor in men. Am J Physiol 1989; 257:

H2033-5. 